\title{
Uterine adenocarcinoma with generalised metastasis in a bottlenose dolphin Tursiops truncatus from northern Patagonia, Argentina
}

\author{
Juana Sánchez ${ }^{1}$, Luisa Kuba ${ }^{2}$, Bárbara Berón-Vera ${ }^{2,3, *}$, Silvana L. Dans ${ }^{2,3}$, Enrique A. Crespo ${ }^{2,3}$, \\ Marie-Françoise Van Bressem ${ }^{4}$, Mariano A. Coscarella ${ }^{2,3}$, Néstor A. García ${ }^{2,3}$, Mariano Koen \\ Alonso $^{2,3}$, Susana N. Pedraza ${ }^{2,3}$, Pablo A. Mariotti ${ }^{2,3}$ \\ ${ }^{1}$ Albarellos 1074 1B, 1641 Acassuso, Buenos Aires, Argentina \\ ${ }^{2}$ Centro Nacional Patagónico (CONICET), Boulevard Brown 3600, 9120 Puerto Madryn, Chubut, Argentina \\ ${ }^{3}$ Universidad Nacional de la Patagonia San Juan Bosco, Boulevard Brown 3700, 9120 Puerto Madryn, Chubut, Argentina \\ ${ }^{4}$ Department of Vaccinology-Immunology, Faculty of Veterinary Medicine, University of Liège, 4000 Sart Tilman, Belgium
}

\begin{abstract}
An endometrial adenocarcinoma with areas of squamous differentiation and generalised metastasis was observed in a bottlenose dolphin Tursiops truncatus stranded in northern Patagonia in July 1997. This is the second report of a uterine adenocarcinoma in a free-living cetacean and the first in a Delphinidae. This neoplasm likely compromised reproduction for several years. In addition, the dolphin presented tattoo-like skin lesions and its digestive tract was infested by Anisakis simplex, Pseudoterranova sp., Braunina cordiformis and Corynosoma australe.
\end{abstract}

KEY WORDS: Bottlenose dolphin - Tursiops truncates $\cdot$ Uterine adenocarcinoma . Tattoo-like skin lesions . Parasites · Patagonia $\cdot$ Argentina

Resale or republication not permitted without written consent of the publisher

Published accounts of genital tumours in female cetaceans are relatively few. These include a likely dysgerminona in a dusky dolphin Lagenorhynchus obscurus (Van Bressem et al. 2000); granulosa cell tumours in 3 beluga whales Delphinapterus leucas (Martineau et al. 1988, De Guise et al. 1994), shortfinned pilot whales Globicephala macrorhynchus (Benirschke \& Marsh 1984, Bossart et al. 1991), 2 fin whales Balaenoptera physalus and a blue whale Balaenoptera musculus (Rewell \& Willis 1949 in Geraci et al. 1987); a mucinous cystadenoma of the ovary in a blue whale (Rewell \& Willis 1949 in Geraci et al. 1987); a uterine adenocarcinoma in a beluga (Lair et al. 1998); uterine leiomyoma or fibroleiomyomas in 2 dusky

${ }^{*}$ Corresponding author. E-mail: barbara@cpsarg.com dolphins (Van Bressem et al. 2000) and a sperm whale Physeter macrocephalus (Uys \& Best 1966), as well as vaginal fibromas in a Blainville's beaked whale Mesoplodon densirostris (Flom et al. 1980) and a finless porpoise Neophocaena phocaenoides (Chen et al. 1982). Other pathologies of the genitourinary system were also observed in pilot whales (Cowan 1966). With the exception of the uterine adenocarcinoma in a beluga whale (Lair et al. 1998), all uterine tumours were benign.

Since the early 1980s, the Laboratorio de Mamíferos Marinos (LAMAMA) of the Centro Nacional Patagónico (CENPAT) has collected and examined carcasses of marine mammals both stranded along the beaches of Patagonia and incidentally caught in fisheries, to study their biology (Dans et al. 1997a, Koen Alonso et al. 1998, 1999, 2000), parasites and diseases (Dans et al. 1999, Berón-Vera et al. 2001, Van Bressem et al. 2001), biogeography and interactions with fisheries (Crespo et al. 1994a, 1997a, Goodall et al. 1994, Dans et al. 1997b), as well as their abundance and population trends (Crespo \& Pedraza 1991, Crespo et al. 1997b, Reyes et al. 1999, Schiavini et al. 1999). To date, more than 600 specimens have been recovered, of which approximately 180 were cetaceans.

During a routine beach combing in northern Patagonia in July 1997, a female bottlenose dolphin Tursiops truncatus that had just died was found at Playa Unión beach $\left(43^{\circ} 24^{\prime} \mathrm{S}, 65^{\circ} 03^{\prime} \mathrm{W}\right)$. The animal was taken to the LAMAMA and autopsied the next day, following standard procedures (Norris 1961). Its age was determined after counting dentinal growth layers on longi- 
tudinal sections of teeth (Crespo et al. 1994b). The number of corpora albicantia (CAs) was determined by standard techniques (Perrin \& Donovan 1984).

The dolphin was $3.2 \mathrm{~m}$ long and weighed $296 \mathrm{~kg}$. It was sexually mature with $43 \mathrm{CAs}$ in the ovaries, including a recent one, and was estimated to be $29 \mathrm{yr}$ old. The abdominal cavity contained at least 81 of a whitish liquid. Numerous whitish to yellowish round (5 to $15 \mathrm{~mm}$ in diameter), firm nodules were scattered on the parietal and visceral peritoneum (Fig. 1), on the abdominal surface of the diaphragm and on the external side of the pericardium (few) as well as on most organs of the abdominal cavity, i.e. ovaries, uterus, kidneys, digestive tract, liver and spleen, causing adherence. The uterus was deformed and appeared as a very firm mass. On section, its wall was greyish, firm and thickened, especially in the uterine body, where it reached approximately 20 to $30 \mathrm{~mm}$. The lumen was reduced although still permeable. The right mesovarium was enlarged (at least $10 \mathrm{~mm}$ in diameter), hard and greyish. The heart and both lungs appeared normal macroscopically.

Representative samples of the uterus, ovaries, kidneys, liver, spleen, diaphragm, lungs and nodules were fixed in formaldehyde $10 \%$ and processed automatically for histopathology. Five $\mu \mathrm{m}$ thick tissue sections were stained with Haematoxilin-Eosin for general morphology, with periodic acid-Schiff (PAS) for glucogen and mucopolysaccharides, with Masson Tricromic for connective and muscular tissues and with silver impregnation for collagen and reticuline fibres.
Microscopically, both the endometrium and myometrium were invaded by abnormal and irregular glands lined by several layers of medium-sized pleiomorphic, epithelial cells, and also by conglomerates of the same cells lacking apparent glandular organisation. The tumoral glands and cords were separated from each other by connective tissue, especially abundant in the myometrium (Fig. 2). The neoplastic cells had an acidophilic cytoplasm, a large nucleus with a prominent nucleolus and an elevation of the nucleocytoplasmic ratio. A PAS-positive secretion was observed in the lumen of some tumoural glands. The number of mitosis in the tumour was moderate. Areas of necrosis were frequently seen in the lumen of the neoplastic glands. Few normal, endometrial glands could still be detected in the endometrium. Aggregations of disorganised cells, probably glandular and resembling those forming the uterine tumour, with necrotic and haemorrhagic areas were observed in the ovaries, kidneys, liver, spleen, diaphragm and nodules. In addition, microfoci of metastasis were detected in the lungs and metastasic embolisms were observed in the lymphatic vessels of the diaphragm, as well as in the arteries and veins of all the organs examined. An abundant fibrous stroma surrounded the neoplastic formations in the kidneys, spleen and diaphragm. Accordingly, the uterine neoplasm and the metastatic lesions were classified as an endometrial adenocarcinoma with areas of squamous differentiation and generalised metastasis.

The metastatic uterine adenocarcinoma may have caused the death of the bottlenose dolphin and is likely

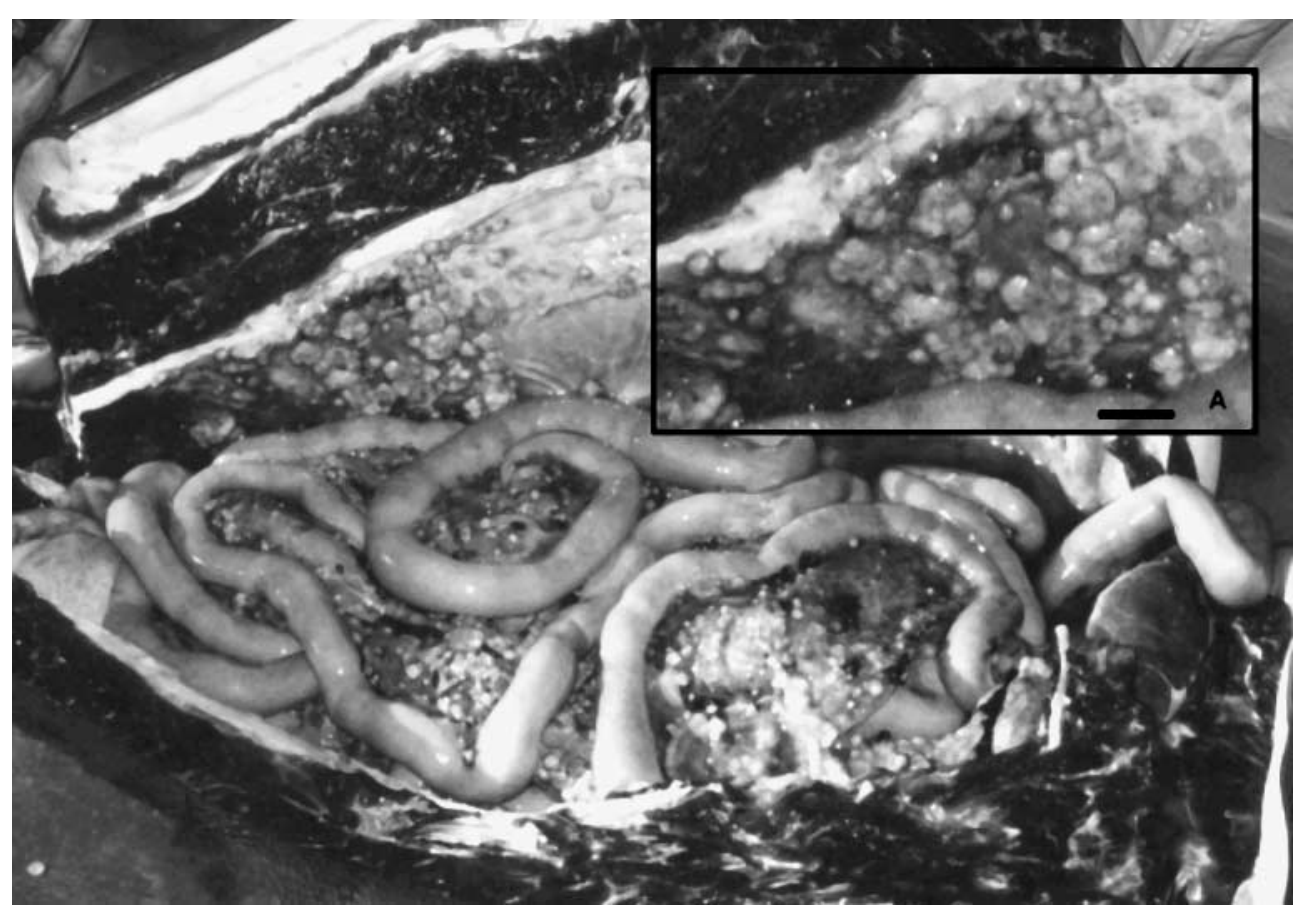

Fig. 1. Ventral view of the abdominal cavity. Numerous nodules are scattered on the parietal and visceral peritoneum as well as on the surface of the intestines. (A) Higher magnification of nodules $($ scale bar $=1.81 \mathrm{~cm})$ 
Fig. 2. Tursiops truncatus uterus. Infiltration of the myometrium by neoplastic endometrial glands and reactive fibrosis PAS, $\times 100$

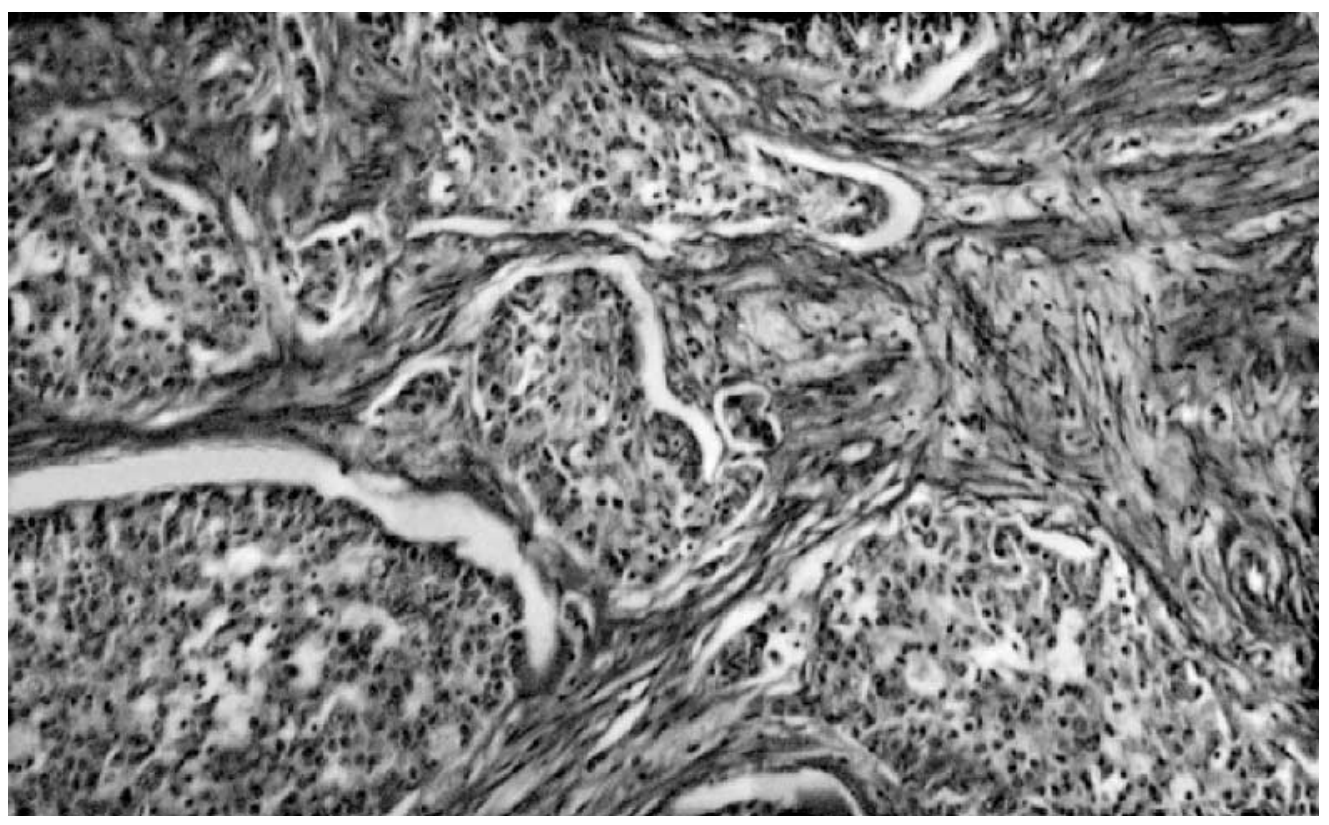

to have compromised its reproduction for several years. This is the second report of a uterine adenocarcinoma in a cetacean and the first in a Delphinidae. Tumours of the genital tract seem to be very rare in the bottlenose dolphin. To our knowledge, they have never been described before in this species although its reproductive system and diseases have been intently studied (Harrison et al. 1972, Harrison \& McBreary 1977, Bossart 1984, Mead \& Potter 1990, Cowan 1995, Miller et al. 1999). Uterine adenocarcinomas also seem to be uncommon in most domestic animals, although several cases have been described in cattle (McEntee 1990, Garcia-Iglesias et al. 1995). A high frequency of endometrial carcinoma (EC) has been observed in virgin laboratory rats $39.1 \%$ in Han/Wistar outbred stock, $62.3 \%$ in DA/Han inbred strain and $\geq 90 \%$ in BD II/Han inbred strain) and in laboratory rabbits ( $\geq 60 \%$ in females older than 4 yr) (Elsinghorst et al. 1984, Deerberg \& Kaspareit 1987). Continuous oestrus due to laboratory conditions and the subsequent persistent high estrogen/progesterone ratio are thought to induce the development of EC in these animals (Elsinghorst et al. 1984, Deerberg \& Kaspareit 1987). Uterine cancer ( $97 \%$ being EC) is the fourth most frequent neoplasm in women and is more common in postmenopausal individuals (Rose 1996). Excessive estrogen is associated with most of the risk factors (nulliparity, obesity, use of unopposed estrogens and late menopause, among others) that have been linked to EC in humans (Rose 1996).

In addition to the adenocarcinoma and generalised metastasis, the dolphin presented 18 tattoo-like skin lesions on the beak and melon. These lesions were irregular, slightly round and measured on average $15.15( \pm 6.16) \times 11.77( \pm 4.9) \mathrm{mm}$ (size range: length 30 to $5 \mathrm{~mm}$, width 24 to $5 \mathrm{~mm}$ ). This is the first report of tattoo-like lesions in cetaceans from the southwestern (SW) Atlantic Ocean. These marks were not detected in >100 small cetaceans examined during routine dissections carried on since the early 1980s and including dusky dolphins Lagenorhynchus obscurus, Commerson's dolphins Cephalorhynchus commersonii, Peale's dolphins L. australis, short-beaked common dolphins Delphinus delphis, bottlenose dolphins Tursiops truncatus and long-finned pilot whales Globicephala melas. True tattoos are caused by unclassified poxviruses and have been observed in 5 species of Delphinidae and 1 species of Phocoenidae from the North Atlantic and the Southeast Pacific (for a review see Van Bressem et al. 1999).

The animal was also infested with several parasites. Individuals of Anisakis simplex and Pseudoterranova sp. (presumably $P$. decipiens) were found in the forestomach (L3 and L4 larval stages as well as adult forms) and main stomach (L3 and L4 larval stages of Pseudoterranova sp. and A. simplex.; adult forms of Pseudoterranova sp.). L3 and L4 larval stages of Pseudoterranova sp. were also found in the duodenal ampoule. The digenean Braunina cordiformis was attached to the wall of the main stomach and at the border between the duodenal ampoule and the duodenum. Adult forms of the acanthocephalan Corynosoma australe infested the intestines. The latest species has been previously observed in dusky dolphins from the SW Atlantic, and infestation of the digestive tract by A. simplex and B. cordiformis has been described in 
dusky dolphins and Commerson's dolphins from these waters (Dans et al. 1999, Béron-Vera et al. 2001). However, it is the first time that these parasites are reported in bottlenose dolphins from the SW Atlantic. It is also the first report of Pseudoterranova sp. in small cetaceans from this ocean province.

Acknowledgements. The authors are indebted to Néstor García (Director of Conservation Issues of the Chubut Province) and Dr. Adán E. Pucci (Director of Centro Nacional Patagónico-CONICET) for institutional support. We kindly thank Norma Bustos for helping with the histology; Atila Gozstonyi for revising the English; and Juan A. Balbuena and Francisco E. Montero for their help in image processing. We are also grateful to 2 anonymous reviewers and Murray Dailey for their useful comments and suggestions. The study of the stranded and incidentally caught specimens was supported by Proyecto Interacciones entre Pesquerías y Mamíferos Marinos en el Litoral PatagónicoFueguino ANPCYT (PICT98 No 01-04025).

\section{LITERATURE CITED}

Benirschke K, Marsh H (1984) Anatomic and pathological observations of female reproductive organs in the shortfinned pilot whale, Globicephala macrorhynchus. Rep Int Whaling Comm Spec Issue 6:451-455

Berón-Vera B, Pedraza SN, Raga JA, Gil de Pertierra A, Crespo EA, Koen Alonso M, Goodall RNP (2001) Gastrointestinal helminths of Commerson's dolphins Cephalorhynchus commersonii from central Patagonia and Tierra del Fuego. Dis Aquat Org 47(3):201-208

Bossart GD (1984) Suspected acquired immunodeficiency in an Atlantic bottlenosed dolphin with chronic-active hepatitis and lobomycosis. J Am Vet Med Assoc 185:1413-1414

Bossart GD, Walsh MT, Odell DK, Lynch JD, Beusse DO, Friday R, Young WG (1991) Histopathologic findings of a mass stranding of pilot whales (Globicephala macrorhynchus). In: Reynolds JE, Odell DK (eds) Marine mammal strandings in the United States. NOAA Technical Report, NMFS 98:85-90

Cowan DF (1966) Pathology of pilot whale (Globicephala melanea), a comparative study. Arch Pathol 82:178-189

Cowan DF (1995) Amyloidosis in the bottlenose dolphin, Tursiops truncatus. Vet Pathol 32:311-314

Chen PX, Liu R, Harrison RJ (1982) Reproduction and reproductive organs in Neophocaena asiaeorientalis from the Yangtze River. Aquat Mamm 9:9-16

Crespo EA, Pedraza SN (1991) Estado actual y tendencia de la población de lobos marinos de un pelo (Otaria flavescens) en el litoral norpatagónico. Ecol Austral 1:87-95

Crespo EA, Corcuera J, López Cazorla A (1994a) Interactions between marine mammals and fisheries in some fishing areas of the coast of Argentina. Rep Int Whaling Comm Spec Issue 15:269-281

Crespo EA, Schiavini ACM, Pérez Macri AG, Reyes LM, Dans SL (1994b) Estudios sobre la determinación de edad en mamíferos marinos del Atlántico Sudoccidental. Anales $4^{\circ}$ RT Espec Mam Mar Am Sur 12-15/11/90, Valdivia, Chile, p 31-55

Crespo EA, Pedraza SN, Dans SL, Koen Alonso M, Reyes LM, Garcia NA, Coscarella MA, Schiavini ACM (1997a) Direct and indirect effects of the highseas fisheries on the marine mammal populations in the northern and central patagonian coast. J North Atl Fish Sci 22:89-207
Crespo EA, Pedraza SN, Coscarella MA, García NA and 6 others (1997b) Distribution and school size of dusky dolphins Lagenorhynchus obscurus (Gray, 1828) in the southwestern South Atlantic Ocean. Rep Int Whaling Comm 47:693-698

Dans SL, Crespo EA, Pedraza SN, Koen Alonso M (1997a) Notes on the reproductive biology of female dusky dolphin (Lagenorhynchus obscurus) off the Patagonian coast. Mar Mamm Sci 13:303-307

Dans SL, Crespo EA, García NA, Reyes LM, Pedraza SN, Koen Alonso M (1997b) Incidental mortality of Patagonian dusky dolphins in mid-water trawling: retrospective effects from the early 80's. Rep Int Whaling Comm 47: 699-704

Dans SL, Reyes LM, Pedraza SN, Raga JA, Crespo EA (1999) Gastrointestinal helminths of the dusky dolphin, Lagenorhynchus obscurus, off Patagonian coasts, in the southwestern Atlantic Ocean. Mar Mamm Sci 15(3):649-660

Deerberg F, Kaspareit J (1987) Endometrial carcinoma in BD II/Han rats: model of a spontaneous hormone-dependent tumor. J Nat Cancer Inst 78:1245-1251

De Guise S, Lagacé A, Béland P (1994) Tumors in St Lawrence beluga whales (Delphinapterus leucas). Vet Pathol 31: 444-449

Elsinghorst TA, Timmermans HJ, Hendriks HG (1984) Comparative pathology of endometrial carcinoma. Vet $Q 6$ : 200-208

Flom JO, Brown RJ, Jones RE, Schonewald J (1980) Vaginal fibromas in a beaked whale, Mesoplodon densirostris. J Wildl Dis 16:99-102

Garcia-Iglesias MJ, Bravo-Moral AM, Perez-Martinez C, Ferreras-Estrada MC, Martinez-Rodriguez JM, EscuderoDiez A (1995) Incidence and pathomorphology of uterine tumours in the cow. Zentbl Vetmed Reihe A 42:421-429

Geraci JR, Palmer NC, St Aubin DJ (1987) Tumors in cetaceans: analysis and new findings. Can J Fish Aquat Sci 44:1289-1300

Goodall RNP, Schiavini ACM, Fermani C (1994) Net fisheries and net mortality of small cetaceans off Tierra del Fuego, Argentina. Rep Int Whaling Comm Spec Issue 15:295-304

Harrison RJ, McBrearty DA (1977) Ovarian appearances in captive delphinids (Tursiops and Lagenorhynchus). Aquat Mamm 5:57-66

Harrison RJ, Brownell RL, Boice RC (1972) Reproduction and gonadal appearances in some odontocetes. In: Harrison RJ (ed) Functional anatomy of marine mammals. Academic Press, London, p 361-429

Koen Alonso M, Crespo EA, García NA, Pedraza SN, Coscarella MA (1998) Diet of dusky dolphins, Lagenorhynchus obscurus, in waters of Patagonia, Argentina. Fish Bull 96: 366-374

Koen Alonso M, Pedraza SN, Schiavini ACM, Goodall RNP, Crespo EA (1999) Stomach contents of false killer whales Pseudorca crassidens stranded in the Strait of Magellan, Tierra del Fuego. Mar Mamm Sci 15(3):712-724

Koen Alonso M, Crespo EA, Pedraza SN, García NA, Coscarella MA (2000). Food habits of the South American sea lion, Otaria flavescens, of Patagonia, Argentina. Fish Bull 98(2):250-263

Lair S, De Guise S, Martineau D (1998) Uterine adenocarcinoma with abdominal carcinomatosis in a beluga whale. J Wildl Dis 34:373-376

Martineau D, Lagace A, Béland P, Higgins R, Armstrong D, Shugart LR (1988) Pathology of stranded beluga whales (Delphinapterus leucas) from the St. Lawrence Estuary, Québec, Canada. J Comp Pathol 98:287-311

McEntee K (1990) The uterus: atrophic, metaplastic and pro- 
liferative lesions. In: McEntee K (ed) Reproductive pathology of domestic mammals. Academic Press, London, p 167-190

Mead JG, Potter ChW (1990) Natural history of bottlenose dolphins along the central coast of the United States. In: Leatherwood S, Reeves RR (eds) The bottlenose dolphin. Academic Press, San Diego, p 165-195

Miller WG, Adams LG, Ficht TA, Cheville NF, Payeur JP, Harley DR, House C, Ridgway SH (1999) Brucella-induced abortions and infection in bottlenose dolphins (Tursiops truncatus). J Zoo Wildl Med 30:100-110

Norris KS (1961) Standardised methods for measuring and recording data on the smaller cetaceans. J Mammal 42(4): 471-476

Perrin WF, Donovan GP (1984) Report of the workshop. Rep Int Whaling Comm Spec Issue 6:1-24

Rewell RE, Willis RA (1949) Some tumours found in whales. J Pathol Bacteriol 61:454-456

Reyes LM, Crespo EA, Szapkievich V (1999) Distribution and population size of the southern sea lion (Otaria flavescens) in central and southern Chubut, Argentina. Mar Mamm Sci 15(2):478-493

Editorial responsibility: Murray Dailey,

Sausalito, California, USA
Rose PG (1996) Endometrial carcinoma. New Engl J Med 335: 640-649

Schiavini ACM, Pedraza SN, Crespo EA, González R, Dans SL (1999) The abundance of dusky dolphins (Lagenorhynchus obscurus) off central Patagonia, Argentina: results from a pilot survey in spring 1995. Mar Mamm Sci 15(3):828-840

Uys CJ, Best PB (1966) Pathology of lesions observed in whales flensed at Saldanha Bay, South Africa. J Comp Pathol 76:407-412

Van Bressem MF, Van Waerebeek K, Raga JA (1999) A review of virus infections of cetaceans and the potential impact of morbilliviruses, poxviruses and papillomaviruses on host population dynamics. Dis Aquat Org 38: 53-65

Van Bressem MF, Van Waerebeek K, Siebert U, Wünschmann A, Chávez-Lisambart L, Reyes JC (2000) Genital diseases in the Peruvian dusky dolphin (Lagenorhynchus obscurus). J Comp Pathol 122:266-277

Van Bressem MF, Van Waerebeek K, Jepson PD, Raga JA amd 13 others (2001) An insight into the epidemiology of dolphin morbillivirus worldwide. Vet Microbiol 81:287-304

Submitted: August 20, 2001; Accepted: October 10, 2001 Proofs received from author(s): February 12, 2002 